.In: Bibliothek in der wissens-gessellschaft: festschrift für Peter Vodosek, ed. A. Blum, and others. 2001. Munchen: K.G. Saur. pp. 19-29. ISBN 3-598-115679

\title{
International Development of Librarianship and Information Science Education and the Role of Research
}

\author{
Ian M. Johnson \\ School of Information and Media, The Robert Gordon University, Garthdee Road, Aberdeen \\ AB10 7QE, Great Britain (i.m.johnson@rgu.ac.uk)
}

\begin{abstract}
This paper considers the role of research in international development programmes. It considers the activities that have been undertaken to establish and develop Schools of Librarianship and Information Science, and some of possible reasons why many have failed to develop once the external support was terminated. It notes that the development of a research profile rarely featured in previous activities, and contrasts this with other disciplines in which the research capacity has made university departments critical to social and economic progress. It notes the real and imaginary obstacles to research and to international cooperation, and outlines the benefits to individuals and institutions of engaging in this type of international collaborative research. Finally, it urges a combined effort to take advantage of the current global interest in information transfer to persuade the development agencies to support research efforts in the applications of librarianship and information sciences.
\end{abstract}

\section{Introduction}

During the third quarter of the last Century, there were what now appear to have been very considerable efforts:

"carried out among or between governmental or non-governmental organisations, groups or individuals to promote, establish, develop, maintain and evaluate library, documentation, and allied services, and librarianship and the library profession generally, in any part of the world." (Parker)

The efforts during that period of international agencies such as UNESCO ${ }^{1}$, the DSE (the German Foundation for International Development ${ }^{2}$, and the British Council ${ }^{3}$ have been well documented, as have the efforts of the United States professional community activities supported by governmental agencies and private foundations. ${ }^{4}$

The Higher Education sector made a significant contribution to international development over the years. The Hochschule fur Bibliotheks- und Informationswesen, played a notable part in these efforts ${ }^{5}$, most recently in helping to found EUCLID: the European Association for Library and Information Education and Research and the BOBCATSSS Conferences ${ }^{6}$ and in its participation in the LISTEN project in Hungary, funded by the European Commission. ${ }^{7}$

There is no doubt that these and similar activities undertaken by other Schools made a significant contribution to the establishment of education for librarianship and information 
sciences. Typically this involved them in releasing staff to undertake reviews and advisory visits or short periods of teaching in order to establish or develop schools of librarianship. However, it appears that some, possibly many of these activities may have had only a limited or short-term impact. It remains the case that in some countries the professional Schools remain weak and underdeveloped, with limited human and material resources, and teaching an out of date and possibly irrelevant curriculum.

We are now entering an era of rapid technological change and proliferating information resources in which information literacy is increasingly widely recognised as important. It is seen as central not only to learning, but also to decision-making, evidence-based practice, and innovation transfer. It is widely believed to have a major impact on the growth of the knowledge economy as well as the prevention of social exclusion. One conclusion that might be drawn from a simple analysis of the condition of library education in some countries or institutions would suggest that what is required is further assistance to enhance the physical resources and to guide the revision of the curriculum. Clearly some further efforts will be necessary to enable Schools of Librarianship and Information Sciences to make, and to be seen to be making, an effective contribution not only to developing the skills needed to make judgements about the relevance of information to synthesise and exploit it rather than simply the ability to identify and retrieve it, but also to promoting an appreciation of the value and impact of information.

However, in addition, it must be acknowledged that in some cases earlier efforts to develop Schools have not always failed to prevent atrophy, and there must therefore be a search for a deeper understanding of the issues that have to be confronted. People experienced in managing or developing library and information science schools and their curricula have pointed to factors likely to underpin development. There have also been studies of the management of Schools of Librarianship in the developed countries, and some analysis of recent closures of Schools in the U.S.A., but there appear to have been no critical evaluation of what contributes to the successful impact of external assistance on the development LIS education nor of its impact on development. The aim of this paper is to consider the state of LIS research in the developing countries, and examine the role that international collaborative research should be playing.

\section{Some reasons for atrophy}

Could it be that part of the problem may be attributable to the failure of the donor agencies to provide appropriate support? How often was external assistance introduced for political reasons by the funding agency, based on that agency's priorities, its perceptions of the needs of the beneficiary institution, and its understanding of the established knowledge and capabilities of the assistance potentially available from its own country or from those institutions or individuals known to the agency's staff? In some cases, it seems fair to suggest that the purpose of the external support and the means of achieving success may not have been clearly defined and understood in advance, and the human and material resource inputs may not have matched the real requirement. In some cases, because of a change in priorities or simply pressure on limited resources, external support has not been sustained for a sufficient period of time for it to be fully effective. A recent review of the British Government's Higher Education Links Scheme (which covers a variety of disciplines) pointed to these as issues requiring attention. ${ }^{8}$ 
Could part of the problem be attributable to the characteristics of the people who become librarians and teachers of librarianship? It has certainly been suggested that students with leadership qualities may not be attracted to the profession because, in the early stages of its development in a country, it appears to offer no promising career or status, and in many cases the few qualified librarians may be being managed by older unqualified personnel, reflecting this in an atmosphere of frustration. ${ }^{9}$

Could part of the problem be attributable to the fact that, in effect, a consultancy service has been provided, and there are inherent limitations in the nature of consultancy activity and the modus operandi of consultants themselves? A consultant is recruited to carry out a specific task, and disseminates the results according to the requirements of the contract, or personal inclination and the availability of time. Consultants' reports may add to factual knowledge and point to outstanding problems, but are sometimes not readily available, even to others working with a similar remit in the same institution. For example, when undertaking a UNESCO mission to Iraq in the 1970s, Ahmed Helal (later University Librarian at Bielefeld) expressed his frustration at:

"the impossibility of finding the reports or knowing the recommendations which had been written by other consultants who recently visited ..." 10

Moreover, few published reports given any insights into the problems that the consultant may face and has to overcome to be successful, for example the internal political complexities. A rare example is a commentary written by Anand Srivastava, another UNESCO consultant of that period, who wrote openly and publicly about his experiences of developing a library school - but only some 5 years afterwards. ${ }^{11}$

There is also a growing belief that that the failure of many library and information sciences schools to develop to their full potential must largely be attributed to the implicit limitations of consultancy activity. A consultant is:

"an individual qualified by education, experience, technical ability, and temperament to advise or assist in a professional basis in identifying, defining, and solving specific library problems as an impartial, objective advisor..." 12

"advising on matters within his expertise; developing new skills or knowledge on behalf of a client..." 13

All too often it appears that the consultants have worked within the limitations of their experience, but have failed to develop the new skills or knowledge that the beneficiary institution and its staff really need. Just as there is growing criticism of the imposition of the British models of library and information services in former colonies in Africa ${ }^{14}$, there is equal concern about the relevance of the Anglo-American model of education for librarianship. ${ }^{15,16}$ These concerns are neither recent nor confined to Africa. The influence of LIS educators from the United States in Latin America has been felt for over seventy years ${ }^{17,18}$, but in the last twenty years it has been recognised some American solutions to the region's information problems were inappropriate because they did not take into account differing cultural, social, and economic conditions ${ }^{19}$, and in the last ten years there have been reports that curricular revisions have been put in train to eliminate excessive American influence. ${ }^{20}$ At the same time, the relevance of teaching intended primarily to meet the needs of advanced, industrialised countries materials produced has begun to be challenged by overseas students in both Britain ${ }^{21}$ and the USA. ${ }^{22}$ In the last twenty years, something has 
clearly begun to change. Whatever it is, it must be understood and incorporated it in future activities.

\section{Research motivation}

There may be other significant factors to emerge from analyses of experts' guidelines and comparisons with the actual patterns of development ${ }^{23}$, but it must be acknowledged that the factors likely to be identified are those that were relevant in the circumstances that applied in the latter half of the last Century. While those efforts that were successful must be applauded, other approaches that do not appear to have been considered or attempted must also be identified and their likely utility must be evaluated. In particular, consideration must be given to what is most likely to be relevant and successful in the circumstances that will be faced in the early years of the new Millennium.

One of the features noticeably absent from most accounts of the development work that has been carried out in the past is evidence of research undertaken or any wide ranging discussion of the part that research might play in national development. It is, of course, fair comment that, in the first stages of development, the capacity for undertaking research may not have existed. There was also inevitable peer pressure to undertake research into the education and training needed by those currently employed in the profession and into its future manpower needs. These research themes were also actively encouraged by both the international professional associations and the intergovernmental agencies. For example, it was a topic in discussions on the relationship between the International Association of Technological University Libraries (IATUL) and FID (Federation Internationale de Documentation) ${ }^{24}$, and the subject of a manual published by UNESCO. ${ }^{25}$

However, it is still the case that in many of the Schools of Librarianship and Information Sciences in the developing countries, there appears to be little research on other topics. The problems that this can cause are recognised in the counties concerned. In Argentina, for example, the absence of critical thought and energy within the library profession in the 1980s was attributed in part to the lack of research and the lack of journals and other publications. ${ }^{26}$ The frustration caused to those who have studied and obtained doctoral degrees in developing countries is also significant. Various obstacles have been suggested as responsible for the lack of library and information science research. In Africa, the reasons put forward for the limited research activity have included: lack of finance; lack of time to carry out research; and a lack of primary periodicals in which to publish research results. ${ }^{27}$

It must be acknowledged that these obstacles are real. In many of the developing countries, the institutional budget does not make much provision for supporting research. A recent report on the situation in Tanzania indicated that the government allocates only $1 \%$ of university budgets to support research, and almost any research must therefore be undertaken with external funds. ${ }^{28}$ In the whole of Latin America, there are no more than about 60 journals in the field ${ }^{29}$; in the Arabic-speaking world there is probably no more than one journal published in each country ${ }^{30}$; and few of them are widely available outside the country of origin.

For potential researchers outside the Anglophone countries, there are additional problems arising from a limited or non-existent familiarity with English. The dominance of the English 
language in professional publishing acts as a barrier to external knowledge, and inhibits the dissemination of the research results. Poor coverage of non-English language journals in the major indexing/abstracting services exacerbates already limited access to bibliographic resources, although coverage of Latin American journals benefits from the efforts of CONACYT, the Mexican National Science Council ${ }^{31}$, and the National University of Mexico's Centre for Library and Information Research. ${ }^{32}$

\section{Overcoming the obstacles}

Despite these obstacles there appears to be a shared belief that it is necessary to find ways of increasing the number of active researchers and improving the means of publication. To overcome the problem of limited research activity, it has been suggested that appropriate professional organisations must take steps to enhance governmental awareness of library needs, but this seems to be a forlorn hope. The experience of at least some universities in developing countries is that, paradoxically, even academics who had studied abroad and were familiar with the potential of modern library services appear to have done little to encourage library development after their return home. ${ }^{33}$

It has also been suggested, in Africa, that research efforts should be focus on the work that can be done by Africans themselves and the professional organisations should help them to seek the required funding. ${ }^{34}$ If approached in the right way, this seems to offer some prospect of success. In most countries the universities are one pool of expertise to which governments and the business community can turn. Universities deliver a nation's educational aspirations, but the knowledge they develop and its application are at the heart of the economy, secure the health of the population, safeguard their culture, and underpin the democratic operation of society. Research provides evidence about existing provision, reveals gaps, highlights issues, and stimulates new ideas that may become the basis of new policies and services. By generating and disseminating knowledge, they advance thinking and create understanding. In developing countries, the universities represent the only pool of expertise readily available locally. ${ }^{35}$ They are the national think tank. Neither governments nor businesses in such countries have the large payroll of highly qualified employees found in the industrialised countries. There is ample evidence of the involvement of other disciplines in providing research services and policy advice to governments in developing countries. ${ }^{36}$

\section{Technical cooperation}

Nonetheless, there still appear to be academics in developing countries who see the opportunities for library and information science research as principally focusing inwards on library education and teaching. ${ }^{37}$ Perhaps not surprisingly, there is also a perception that development agencies are not interested in librarianship and information science research. Given the focus on such issues by the development funding agencies, there appear to be opportunities for the Schools of Librarianship and Information Sciences in the industrialised countries to focus their expertise on researching the role of information and information services in support of relevant aspects of development. It is therefore encouraging that, despite the alleged obstacles, considerable progress has already been made in research into, for example, medical librarianship ${ }^{38}$ and community information services. ${ }^{39}$ 
International collaborative research does present a number of challenges for the Schools in the industrialised countries. Their national research funding agencies are likely to be inward looking, and probably reluctant to support research that has no immediate application in their own country. How then can a relationship be developed, or at least a new level of interest be fostered, amongst the agencies that fund international development and research? Equally important is how to develop appropriate partnerships with Schools in the developing countries. To what extent should greater efforts be made to retain and build on the links that are established with overseas students who attend Schools in the developing countries? What is the role of international organisations such as IFLA (the International Federation of Library Associations and Institutions) in facilitating these links?

In the past, the initiative for collaboration has often been taken in the developing countries, and the needs of the Schools have often been seen as a short term updating of the curriculum and associated development of their human and material resources. How can the Schools and the development agencies be persuaded to accept that engaging in collaborative research offers them some greater hope of becoming self-sustaining in the medium term? How can research projects be identified that are likely to attract the attention of the government of the country concerned and the support of a funding agency? Do the Schools in the industrialised countries do enough to encourage overseas students to focus their research interests on topics that are relevant to their countries' needs? How often do teachers from Schools of librarianship in the industrialised countries writing their dissertations about aspects of curriculum or manpower development as it affects their School? Does this theme recur with unwarranted frequency in the work of teachers from the developing countries?

There are other problems that the Schools in the developed countries must face. How can they ensure access to appropriate sources of information? If they undertake research within their existing specialisms, they should already have the core material. How can they ensure the professional commitment of their staff? Staff will find an additional outlet for their existing research interests, the possibility of new sources of support, and perhaps some new methodological challenges and fresh insights. How can they ensure the support of their institution? Recently financial pressures on higher education in many of the industrialised countries, and the contractual constraints that the institutions are imposing on academics' time, appear to have been creating an attitude within some Universities that may be inimical to any activity that appears to subsidise international development. However, the approach discussed here should mean that the employing institution would benefit from the facilitation of the legitimate research interests of its academic staff, and from the associated staff development. ${ }^{40}$ In short, if they concentrate on their own areas of expertise, these issues should not be a problem.

\section{Mutual benefits}

It is almost universally accepted that doing some form of research is a required activity for university teachers, not least because it provides the material they require for teaching their students. Moreover, a recent study in Britain has reported that both undergraduate and postgraduate students believe that research activity not only makes sure that their teachers are up to date and increases their credibility, but also makes them more enthusiastic. ${ }^{41}$ In short, it helps to make them better teachers. 
For those who are committed to research, whether in the developed or the developing countries, international collaboration in research offers a number of benefits. It introduces them to new opportunities for research, and develops a wider range of professional contacts with similar research interests. It may require them to adopt new, inter-disciplinary approaches and develop the range of their competences. It also attracts additional funding, which will not only attract kudos, but may provide some improvement in the resource base of the Schools in the developing countries.

For the Schools in the developing countries there are additional benefits in international collaboration. It may provide access to relevant publications, case studies, etc. produced in the developing world, and possibly assistance in overcoming any language barrier in making use of that resource. The availability of local partners may also help overcome the problems of inter-cultural communication. There is a growing understanding, at least amongst experts in communication, that interpretation often requires more than a literal translation of a text ${ }^{42}$, and that it needs to take account of different cultural and terminological concepts. ${ }^{43}$

There are also particular benefits or the Schools in the developing countries in international collaboration. Their staff may have access to the richer resources of the Schools in the developed countries. Research will not only raise their awareness of the potential demand for services, the availability of relevant skills and financial resources, and a political and managerial attitudes towards the role and development of library and information services. It develops their capacity to produce accurate and timely data, to undertake analysis, and to feed back into policy making. ${ }^{44}$ It also cannot fail to contribute to a School's clearer understanding of professional manpower requirements in the country, revisions required in their curricular content, and staff development needs in both the Schools and the nation's library and information services. These are probably the issues that are most likely to motivate and mobilise change, and help them pass new thresholds of performance.

The publication of the results of their work in the developed or the developing countries not only raises awareness of the issues, but also raises their profile and national and international standing of the collaborating institutions and the individual researchers. ${ }^{45}$ It may also be seen as having a direct impact not only on improving library and information services, but also on the political influence of the LIS profession on society, ensuring that it is not left on the periphery of affairs.

\section{Concluding remarks}

Perhaps the most important issue that requires attention is how to capture the interest and support of the development funding agencies.

In recent years, it must be acknowledged that there appears to have been a decline in international collaborative activity, notwithstanding a short-lived engagement with the professional community in the former Soviet Union and its east European satellite states. The decline in UNESCO support in the last 5 years ${ }^{46}$, based on its reduced budget and a lack of political support for work in this area, is well known, but the contraction of the activities of some of the other national development agencies has attracted less attention, although the causes are the same. The British Council, for example, once played a major role in leading the development of librarianship and information work world-wide, particularly by 
contributing to collection building in key institutions and by supporting the development of their staff to modernise services. Recent reductions in the Council's budget and the number of posts overseas for library and information specialists appear to have curtailed its developmental activities in this field at a time when they are becoming more globally significant.

However, there appears to be the beginnings of a shift in the interests of the development agencies, which may benefit library and information science education and research. The concept of the "information society" has been promoted for several years in policy statements and action plans by inter-governmental agencies such as the European Commission, the G7 group of the world's wealthiest industrialised nations, and UNESCO. Many European countries are now actively promoting information society strategies and action plans and have been thinking strategically about their information societies for some time. In addition, a report recently published by the World Bank and UNESCO has called for a decisive shift in government priorities to provide greater support for the development of higher education, arguing that increased numbers of highly skilled people are needed in the knowledge economy that is emerging largely as a result of the rapid introduction of enhanced Information and Communications Technologies (ICTs). ${ }^{47}$ There also appears to be an increased willingness on the part of major private foundations such as Carnegie, Gates and Mellon to support international development activities in libraries and information services.

The underlying concept of the 'Information Society' is essentially a concern with 'information' products and services, and the way in which they are changing. However, these changes give rise to equally fundamental changes in the way information is used and its impact on every aspect of economic, educational and social activity. Effective use of information is recognised as a key success factor within a knowledge economy and within an innovation-driven society in which:

"learning and command of knowledge have become the key success factors of international competitiveness. 70-80\% of economic growth is said to be due to new and better knowledge..."

The challenges facing developing countries in achieving the economic and social advances that are held in prospect by these changes are not only in implementing the necessary improvements in their technical and regulatory infrastructures, but also in creating a society and workforce with the required knowledge, skills, and attitudes to make use of applications of ICTs and benefit from them. This, surely, provides ample scope for research?

It is, therefore, important that we recognise that while the activities of these agencies have declined, their influence has not diminished. When UNESCO turned its attention to the conservation of libraries and archives, through its 'Memory of the World' programme, it captured the attention of the member states. The energy that the British Council mobilised in securing the interest of the World Bank in the role of library and information services was impressive. Its support for the HEIDI project (Higher Education Investment in the Development of Information), a series of case studies of 4 countries on 4 different continents with contributions from over 100 international library and information science experts was aimed at assessing the current thinking and determining strategic policy on investment in higher education libraries and information services worldwide. ${ }^{49}$ The associated lobbying activities were a significant influence in the establishment of the World Bank's infoDev ${ }^{50}$ programme. It is now seeking to play a similar role in the Global Knowledge Partnership ${ }^{51}$, a grouping of over sixty international organisations committed to ensuring that developing 
countries benefit from appropriate and sustainable investment in the new ICTs. The task of the LIS research community is to ensure that the role and contribution of research into librarianship and information services to economic and social development, and in moving forward the agendas of infoDev and the Global Knowledge, is fully appreciated and receives greater support.

The policies of UNESCO's Division for Communication, Information and Informatics are driven by the wishes of the member states. Those of other development agencies are driven by the opinions put forward persuasively to politicians and senior government administrators, in both the developed and developing countries. It is important that IFLA's member associations and institutions contribute to that debate through their national UNESCO Commissions and appropriate government Ministries, and that IFLA engages fully in the global debate about education and research activities in the field of librarianship and information sciences. IFLA's Executive and Professional Boards now hold an annual meeting with the Presidents and Chief Executives of the member associations, and there must be an effort to ensure that international collaborative research is on the agenda of those meetings. EUCLID also has a role to play, in making representations to the relevant parts of the European Commission.

A few years ago, in a paper presented at the IFLA Conference in Copenhagen ${ }^{52}$, this author expressed the opinion that the Schools of Librarianship in Europe were not sufficiently involved in the electronic library development programmes funded by the European Commission. At the time it provoked some comment from a member of the Commission's staff who was in the audience, and at a conference the following Spring, he presented a paper with a fairly comprehensive account of the Commission's involvement with professional education. ${ }^{53}$ That may have been a coincidence - he certainly does not appear to have responded directly or fully to the points that had been made, - but it may be a small indication that if voices are raised they may be heard. However, if the LIS research community is to be really effective, it is important that its members not only make the case in public, but that they also do it in more private fora, and that they all say much the same thing.

${ }^{\circledR}$ The author 2001

\section{AUTHOR}

Ian Johnson has been Head of the School of Information and Media at The Robert Gordon University, Aberdeen, Scotland since 1989. There he is responsible for 26 academic staff and 8 researchers, and about 500 undergraduate and postgraduate students taking courses in library and information sciences, publishing studies, and corporate communication.

Previously he was in charge of industry liaison and continuing education programmes at the College of Librarianship Wales (the University of Wales School of Librarianship and Information Studies); Assistant to the British Government's Advisers on library matters; and an operational manager in public libraries.

He was Chairman of the IFLA Section on Education and Training from 1991 to 1993, and Chairman of the IFLA Professional Board from 1993 to 1995. From 1993 to 1995 he was also Chairman of the (British) Library Association's Personnel, Training and Education Group, and 
from 1996 to 2000 represented the Group on the Council of The Library Association. From 1997 to 2000 he was Chairman of the Heads of Schools and Departments Committee of BAILER: the British Association for Information and Library Education and Research. He is currently Chairman of the Executive Board of EUCLID: the European Association for Library and Information Education and Research; joint editor of Libri: international journal of libraries and information services; and a member of the Editorial Board of Education for Information.

\section{REFERENCES}

${ }^{1}$ PARKER, J.S. UNESCO and library development planning. 1985. London: The Library Association.

${ }^{2}$ HUTTEMAN, Lutz. Information training for Africa: the role of the German Foundation for International Development. Information Development, 6 (2), 1990, 84-88

${ }^{3}$ COOMBS, D. Spreading the word: the library work of the British Council. 1988. London: Mansell

${ }^{4}$ BREWSTER, B.B. American overseas library technical assistance, 1940-1970. 1976. Metuchen, New Jersey. Scarecrow Press

${ }^{5}$ VODOSEK, P. National and regional models of collaboration between teaching and research institutions within the field of library and information science: with the Fachhochschule fur Bibliothekswesen Stuttgart (FHB) as an example. Education for Information, 12(3), September 1994, 367-78

${ }^{6}$ JOHNSON, I.M. The role of associations of information and library education in teaching and research: recent and potential developments in Britain and Europe. Education for Information, 18 (3/4), 2000, 201-220

${ }^{7}$ A konyvtaros es informacios szakemberkepzes megujitasa - Renewing the education and training of librarians and information professionals: proceedings of the closing conference of the LISTEN TEMPUS JEP (1994-97); Berzsenyi College, Szombathely, Hungary, 25th to 27th June 1997. 1997. Hungary: Szombathely, Berzsenyi College. ISBN 9639017256

${ }^{8}$ ELDRIDGE, D., and others. Evaluation of the Higher Education Links Scheme: contract CNTR 999253. [2000. British Council/University of Manchester.] (Unpublished typescript)

${ }^{9}$ MANZOOR, S. Trends of library users: a study in Iraqi scene. Indian Librarian, 35 (1), June 1980, 9-17

${ }^{10}$ HELAL, A.H. Iraq: Scientific Documentation Centre; February - April 1972. Paris: UNESCO. Doc. Code. 2736/RMO.RD/DBA; FR/PP/Consultant. (Limited). 1972.

${ }^{11}$ SRIVASTAVA, A.P. An account of expert missions of the UNESCO and the United Nations in the Middle East. Indian Librarian, 29 (1), June 1974, 33-37.

${ }^{12}$ LOCKWOOD, J.D. Involving consultants in library change. College and research libraries, 38 (6), November 1977, 498-508

${ }^{13}$ LIBRARY ASSOCIATION and INSTITUTE OF INFORMATION SCIENTISTS. Guidelines for consultants working in librarianship and information science. Library Association Record, 86 (4), April 1984, 174-175

${ }^{14}$ STURGES, P. The poverty of librarianship: an historical critique of public librarianship in Anglophone Africa. Libri, 51 (1), 2001, 38-48

${ }_{15}^{15}$ MCHOMBU, K. Which way African librarianship? IFLA Journal, 17(1), 1991, 26-38

${ }^{16}$ TITI, M. The relationship between curriculum, learning and teaching in library and information science with special reference to the University of Transkei. 2001. PhD thesis. University of Loughborough.

${ }^{17}$ MUELLER, S.P.M. O ensino de biblioteconomia no Brasil. [The teaching of librarianship in Brazil.] Ciencia da Informacao, 14 (1), January/June1985, 3-15

${ }^{18}$ SOUZA, F.d.C.d. Ensino de biblioteconomia no Brasil: o modelo Norte-Americao. [Library science teaching in Brasil: a North-American model.] Informacao \& Sociedade: Estudos, 3 (1), 2 1993, 1-5

${ }^{19}$ GOLDSTEIN, E. Tranferability of American library and information science education to Mexico. in Information interaction: proceedings of the 45th ASIS Annual Meeting, Columbus, Ohio, 17-21 October 1982; edited by A.E. Petrarca, C.I. Taylor and R.S. Kohn. 1982. White Plains, New York, Knowledge Industry Publications, Inc. pp. 116-118

${ }^{20}$ CESARINO, M.A. da N. and Vianna, M.M. O curso de graduacao em Biblioteconomia da UFMG. [The undergraduate librarianship course at Universidad Federal do Minas Gerais Library school.] Revista da Escola Biblioteconomia da UFMG, 19 (special), March 1990, 37-67

${ }^{21}$ Conference on education of overseas students in U.K. educational institutions, London, 25-26 March 1992. Education for information, 10 (4), December 1992, Special issue 
${ }^{22}$ TALLMAN, J.I. and OJIAMBO, J.B. editors. Translating an international education to a national environment: papers presented at the international doctoral student conference sponsored by the Doctoral Guild at the University of Pittsburgh School of Library and Information Science, September 23-25, 1988. 1990. Metuchen, N.J. and London: Scarecrow Press.

${ }^{23}$ JOHNSON, I.M. Effective development of education for librarianship and information management: a preliminary analysis of critical success factors. Forthcoming paper.

${ }^{24}$ HILL, M.W. Co-operation between FID and other organisations involved in the library and information fields. IATUL Quarterly, 3 (3), September 1989, 158-161

${ }^{25}$ MOORE, N. Guidelines for conducting information manpower surveys. 1986. Paris: UNESCO. ref. PGI$86 / \mathrm{WS} / 3$

${ }^{26}$ SABOR, J.E. The issue of librarianship in Argentina. Third World Libraries, 3 (1), Fall 1992, 40-46

${ }^{27}$ ALEMNA, A. A. Library and information research in Africa: obstacles and opportunities. International Journal of Information and Library Research, 5 (1), 1993, 47-55

${ }^{28}$ COUNCIL FOR INTERNATIONAL COOPERATION IN HIGHER EDUCATION. Higher education links: evaluation mission to Tanzania, Uganda, Zimbabwe; February-March 2000. 2000. London: \{British Council] CICHE. Appendix 3, p.2. (Unpublished typescript)

${ }^{29}$ MORALES CAMPOS, E. (1997) Latin America and the Caribbean in A. Large, ed. World Information Report 1997/98. Paris: UNESCO Publishing. pp.107-123. (see Table 2, p. 120)

${ }^{30}$ Meeting of experts on the education of information specialists in the Arab region: Ecole des Sciences de l'Information, Rabat, Maroc (10-13 May 1993). Final Report. Paris: UNESCO. (ref. PGI-93/WS/13)

${ }^{31}$ JOHNSON, I.M. Recent developments in library automation in Mexico and Venezuela. Program, 21 (4), October 1987, 379-381

${ }^{32}$ JOHNSON, I.M. Management development for libraries and information services in Latin America and the Caribbean. International Information and Library Review, 31 (4), December 1999, 225-244

${ }^{33}$ MANZOOR, S. Trends of library users: a study in Iraqi scene. Indian Librarian, 35 (1), June 1980, 9-17

${ }^{34}$ OBAKA, D.N. The challenge of medical librarianship in Africa. Third World Libraries, 2 (1), Fall 1991, 1416

${ }^{35}$ WORLD BANK. Revitalising universities in Africa. 1997. World Bank. p.3

${ }^{36}$ COUNCIL FOR INTERNATIONAL COOPERATION IN HIGHER EDUCATION. Higher education links: evaluation mission to Tanzania, Uganda, Zimbabwe; February-March 2000. 2000. London: \{British Council] CICHE. (Unpublished typescript)

${ }^{37}$ ALEMNA, A. A. Library and information research in Africa: obstacles and opportunities. International Journal of Information and Library Research, 5 (1), 1993, 47-55

${ }^{38}$ OBAKA, D.N. The challenge of medical librarianship in Africa. Third World Libraries, 2 (1), Fall 1991, 1416

${ }^{39}$ ABOYADE, B.O. The provision of information for rural development. Ibadan, Nigeria: Fountain Publications, 1987.

${ }^{40}$ JOHNSON, I.M. Staff development in international technical cooperation programmes: the case of the TEMPUS Joint European Project 'LISTEN'. Information Development, 13 (4), December 1997, 197-202

${ }^{41}$ UTLEY, A. Research makes you teach better. Times Higher Education Supplement, 1479, March 23, 2001.

${ }^{42}$ WINTERS, E. Eleven commandments of localization. Active Voice (Society for Technical Communication), June 1994; republished 1996 by International Interactive Communications Society. Viewed on the Web on 25 January, 2000 at URL - http://www.bena.com/ewinters/local.html

${ }^{43}$ GAEDE, B. Courseware and user interfaces across cultural borders (Courseware variants: content and user interfaces to provide information access for almost everybody) in Access 2000: intellectual property vs the right to knowledge? proceedings of the 8th international BOBCATSSS symposium on library and information science, Jagiellonian University, Krakow, Poland, January 24 - 26, 2000. 2000. Copenhagen, Denmark: Royal School of Library and Information Science. pp. 161-172

${ }^{44}$ COUNCIL FOR INTERNATIONAL COOPERATION IN HIGHER EDUCATION. Higher education links: evaluation mission to Tanzania, Uganda, Zimbabwe; February-March 2000. 2000. London: \{British Council] CICHE. p.44. (Unpublished typescript)

${ }^{45}$ COUNCIL FOR INTERNATIONAL COOPERATION IN HIGHER EDUCATION. Higher education links: evaluation mission to Tanzania, Uganda, Zimbabwe; February-March 2000. 2000. London: \{British Council] CICHE. p.14. (Unpublished typescript)

${ }^{46}$ JOHNSON, I.M. UNESCO and human resource development for the 'Information Society' Education for Information, 16 (3), September 1998, 237 - 242.

${ }^{47}$ World Bank/UNESCO, Joint Task Force on Higher Education and Society. Higher Education in Developing Countries: Peril and Promise. 2000. World Bank 
${ }^{48}$ DEPARTMENT OF TRADE AND INDUSTRY, Technology Foresight - Information, Communications and Media Panel. Point and click - learners in the ICT driving seat: a consultation document. 2000. Viewed on 27 November 2000 at URL - http://www.foresight.gov.uk

${ }^{49}$ ILIAD (International Library and Information Action for Development). Higher education library and information service development: strategies for investment. 1995. British Library. Research and Development Department. BLRD Report 6221

${ }^{50}$ The infoDev website was viewed on $27^{\text {th }}$ March 2001 at URL http:// www.infodev.org/

${ }_{51}^{51}$ The Global Knowledge website was viewed on $27^{\text {th }}$ March 2001 at URL http://www.globalknowledge.org/

${ }^{52}$ JOHNSON, I.M. The development of education and research for the electronic library - opportunities and challenges: paper presented to the meeting of the Section on Education and Training during the I.F.L.A.

conference, Copenhagen, August 1997. (I.F.L.A. Conference papers ref. 107-SET-3-E)

${ }^{53}$ STORK, H-G. European initiatives for the professional development of librarians: paper presented to the 4th European Bielefeld Colloquium on Libraries and Publishers as Main Players in the Information Society, 10-12 February 1998. Viewed on the Web on 1 February, 2000at URL http://www.cordis.lu/libraries/en/biel-geo.html 